\title{
Analysis of long-term dynamics of the plankton community of Lake Baikal
}

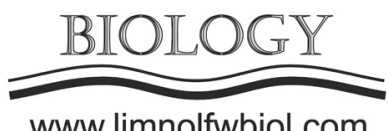

www.limnolfwbiol.com

\author{
Rusanovskaya O.O., Shimaraeva S.V., Karnaukhov D.Y., Krashchuk L.S., \\ Pislegina E.V., Silow E.A.*
}

Irkutsk State University, Karl Marx str., 1, Irkutsk, 664003, Russian Federation

\begin{abstract}
Analysis of long-term observations after plankton community of Lake Baikal has demonstrated the tendencies of the increase of the temperature of water for the upper $50 \mathrm{~m}$ layer for the last 70 years, of water transparency and chlorophyll $a$ concentration during the season of the open water for the last 40 years. Analysis of the dynamics of the dominant species of phytoplankton has shown the increase of number of non-endemic small-cell species of diatom algae Synedra acus some increase of the number of endemic species Gymnodinium baicalense with simultaneous tendency of decrease of the number of endemic large-cell species of under-ice developing diatom algae. Analysis of dynamics of number of zooplankton has demonstrated that the number of copepods, of endemic under-ice as well as non-endemic year-round rotifers are decreasing, while the number of cladocers, and non-endemic rotifers, developing during end of summer and autumn increases during the last 70 years. We have fulfilled comparative analysis of the results of our monitoring observations of Lake Baikal plankton and the results for other lakes of the World and we are to conclude that the observed trends can be explained by Global, particularly Climate, Change.
\end{abstract}

Keywords: Lake Baikal, Global Change, Climate Change, plankton, water temperature, water transparency, chlorophyll $a$, phytoplankton, zooplankton, endemic species

\section{Introduction}

Lake Baikal is situated in the middle of Eurasia, and is rather far from industrially or agriculturally developed regions and was relatively safe from human influence until XX century. Ecological monitoring of Lake Baikal plankton community is fulfilled since 1945 (Kozhov, 1963; Kozhova and Izmest'eva, 1998) and now presents an example of the longest raw of lake plankton observation in the World.

Recent research is an attempt to find trends in Lake Baikal plankton community influenced by Global Change. We analyzed the long-term dynamics of dominant species of phytoplankton and practically all species of net zooplankton (copepods, cladocerans, rotifers).

\section{Methods}

Plankton samples have been collected at one stationary point ("Point \#1") situated in the Southern Baikal in the vicinity of Bolshie Koty settlement. Sampling station coordinates are $51^{\circ} 52^{\prime} 48^{\prime \prime} \mathrm{N}$, $105^{\circ} 05^{\prime} 02^{\prime \prime} \mathrm{E}$, distance to shoreline $2,7 \mathrm{~km}$, depth 800 $\mathrm{m}$. Samples were taken weekly-biweekly all the year round since 1945, excluding two brakes per year during ice melting and freezing, when the sampling point is inaccessible both by ship as well as by walking. Phytoplankton was sampled with $10 \mathrm{~L}$ Van Doorn bottle from the depths of $0,5,10,25,50,100,150$, 200, $250 \mathrm{~m}$, fixed with Utermöhl solution since 1973. Before 1973 phytoplankton was fixed with formalin that lead to elimination of too tiny forms of algae. Zooplankton was sampled with closing net $37.5 \mathrm{~cm}$ in diameter, $100 \mu \mathrm{m}$ mesh) from the layers $0-10,10-25$, 25-50, 50-100, 100-150, 150-200, 200-250 m. Samples were enumerated at the species level (for phyto- and zooplankton) and age stage (for zooplankton) with light microscope (about 500 forms of phytoplankton and 800 forms of zooplankton). Temperature of water was measured with mercury thermometer retrieved with Van Doorn bottle at depths of 0, 5, 10, 25, 50, $100,150,200,250 \mathrm{~m}$, samples for chlorophyll a were collected at these depths too.

We operated with $0-50 \mathrm{~m}$ weighted averages for biotic (algae and zooplankton density, chlorophyll concentration) and abiotic (temperature for correlation analysis) parameters as $0-50$ is the layer of the lake Baikal, where the most production processes take place. For the algae we've used the maximum density observed 
in the year as it is the real parameter reflecting the possibilities of algae species under current conditions.

\section{Results and discussion}

Analysis of long-term observations after plankton community of Lake Baikal has demonstrated the tendencies of the increase of the temperature of water for the upper $50 \mathrm{~m}$ layer for the last 70 years, of water transparency and chlorophyll a concentration during the season of the open water for the last 40 years. Analysis of the dynamics of the dominant species of phytoplankton has shown the increase of number of non-endemic small-cell species of diatom algae Synedra acus Kützing, some increase of the number of endemic species Gymnodinium baicalense Antipova with simultaneous tendency of decrease of the number of endemic large-cell species of under-ice developing diatom algae Aulacoseira baicalensis (Wislouch) Simonsen, Aulacoseira islandica (O. Müller) Simonsen, Stephanodiscus meyerii Genkal et Popovskaya, Cyclotella minuta (Skvortzov) Antipova. Analysis of dynamics of number of zooplankton has demonstrated that the number of copepods (both endemic Epischura baikalensis Sars as well as non-endemic Cyclops kolensis Liljenborg), of endemic under-ice (Synchaeta pachypoda Jaschnov, Synchaeta pachypoida Kutikova et Vassiljeva, Notholca grandis Voronkov, Notholca intermedia Voronkov, Collotheca sp.) as well as non-endemic yearround (Kellicottia longispina Kellicot, Keratella quadrata Muller, Keratella cochlearis Gosse, Filinia terminalis
Plate) are decreasing, while the number of cladocers (Daphnia longispina O.F. Müller and Bosmina longirostris O.F. Müller), and non-endemic rotifers (Synchaeta stylata Wierzejski, Conochilus unicornis Rousselet, Euchlanis dilatate dilatate Ehrenberg, Euchlanis dilatate unisetata Leydig, Asplanchna priodonta priodonta Gosse, Asplanchna herricki Guerne, Bipalpus hudsoni Imhof, Collotheca mutabilis Hudson, Synchaeta sp., Synchaeta sp. sp., Polyarthra sp.), developing during end of summer and autumn increases during the last 70 years.

We have fulfilled comparative analysis of the results of our monitoring observations of Lake Baikal plankton and the results for other lakes of the World and we are to conclude that the observed trends can be explained by Global, particularly Climate, Change.

\section{Acknowledgements}

The research was supported by Grants of RSCF project \# 18-44-06201, of Ministry of Higher Education and Research (projects № FZZE-2020-0026; № FZZE-2020-0023), and of Foundation for support of applied ecological studies «Lake Baikal» (https:// baikalfoundation.ru/project/tochka-1/ ).

\section{References}

Kozhov M.M. 1963. Lake Baikal and its life. The Hague: Dr. W. Junk. DOI: 10.1007/978-94-015-7388-7

Kozhova O.M., Izmest'eva L.R. 1998. Lake Baikal: evolution and biodiversity. 2nd enlarged edition. Leiden: Backhuys Publishers. 